\title{
Carbon Dioxide as a Potential Water Disinfestant for Phytophthora Disease Risk Mitigation
}

\author{
Ping Kong, Virginia Tech, Hampton Roads Agricultural Research and Extension Center, Virginia Beach 23455
}

\begin{abstract}
Kong, P. 2013. Carbon dioxide as a potential water disinfestant for Phytophthora disease risk mitigation. Plant Dis. 97:369-372.

The spread of Phytophthora spp. through irrigation systems and natural waterways can have a significant impact on plant health and requires mitigation. Pressurized carbon dioxide $\left(\mathrm{CO}_{2}\right)$ can inactivate Phytophthora nicotianae zoospores but its effectiveness at low pressure and on other species was unknown. This study evaluated the effect of injected $\mathrm{CO}_{2}$ at 63 to $4,000 \mathrm{ppm}$ in irrigation water on zoospore survival of four Phytophthora spp. and infectivity of $P$. nicotianae zoospores. Zoospore survival of $P$. nicotianae, $P$. tropicalis, and $P$. pini was reduced by over $90 \%$ at $4,000 \mathrm{ppm}$ and was reduced by $40 \%$ at 125 to 2,000 ppm after a 2-h exposure. Survival of P. megasperma was less

affected by injected $\mathrm{CO}_{2}$, with a reduction of $37.1 \%$ at $\leq 4,000 \mathrm{ppm}$. $\mathrm{CO}_{2}$ treatments at $4,000 \mathrm{ppm}$ for 30 or $120 \mathrm{~min}$ of water infested with P. nicotianae at zoospore concentrations of 1,000 and $5,000 \mathrm{ml}^{-1}$ reduced disease incidence of annual vinca (Catharanthus roseus) by 92 and $75 \%$. Comparable efficacy was observed in the $\mathrm{CO}_{2}$ treatment at $2,000 \mathrm{ppm}$. The $\mathrm{CO}_{2}$ treatments at $<2,000 \mathrm{ppm}$ also significantly reduced disease caused by water infested at 1,000 zoospores $\mathrm{ml}^{-1}$. These results indicate that $\mathrm{CO}_{2}$ may have potential as a safe and effective water disinfestant for Phytophthora spp.
\end{abstract}

The spread of many plant pathogens, including the causal agent of sudden oak death in forestry and horticultural industries, has been associated with infested irrigation water sources $(3,11,26)$. Chlorination is a widely used water treatment because of its effectiveness and relatively low cost at the recommended concentration of $2 \mathrm{ppm}$ (13). However, chlorine gas is extremely hazardous and its effectiveness is influenced by $\mathrm{pH}$, organic and inorganic chemicals in the water, and other factors $(13,14,23)$. Chlorination is most efficacious at a $\mathrm{pH}$ of 5 to 6.5 , and its efficacy drops with increasing $\mathrm{pH}$ (e.g., it can be as low as $20 \%$ at $\mathrm{pH}$ 8) $(13,22)$. Such low efficacy may be common because $\mathrm{pH}$ in many irrigation water sources is high (up to 10.3), particularly during growing seasons (10).

It has been known for more than 100 years that carbon dioxide $\left(\mathrm{CO}_{2}\right)$ can exert an inhibitory effect on microbial growth (27). $\mathrm{CO}_{2}$ has been used in the food industry and elsewhere for inactivation of microorganisms because of its safe, cost-effective, and straightforward application without extensive safety training and equipment. Pressurized $\mathrm{CO}_{2}$ has been used as a fumigant or injected into juice or milk to kill microorganisms, preventing food spoilage and increasing shelf life $(4,7,8,15,19,25)$. Its use has also been extended to sewage treatment for Escherichia coli contamination (20). For plant pathogens, pressurized $\mathrm{CO}_{2}$ has been effective for inactivating Phytophthora nicotianae inocula $(1,2)$. In recent studies, $\mathrm{CO}_{2}$ was shown to work well at low pressures for inactivation of microorganisms in liquids $(1,5,21,24)$. The treated liquid becomes weakly acidic due to dissolved $\mathrm{CO}_{2}$ effectively killing $\mathrm{pH}-$ sensitive microbes $(1,5) . \mathrm{CO}_{2}$ as an acidifier could improve chlorination efficiency and also, by low $\mathrm{pH}$ itself, suppress Phytophthora spp., including $P$. ramorum, which are favored by a basic environment $(17,18)$. However, little information is available regarding the effectiveness and cost of $\mathrm{CO}_{2}$ as a disinfestant or acidifier. This study tested the efficiency of different concentrations of injected $\mathrm{CO}_{2}$ in irrigation water on zoospore survival and resulting plant infection.

Corresponding author: P. Kong, E-mail: pkong@vt.edu

Accepted for publication 28 September 2012.

http://dx.doi.org/10.1094/PDIS-09-12-0844-RE

(C) 2013 The American Phytopathological Society

\section{Materials and Methods}

Pond water processing and $\mathrm{CO}_{2}$ treatments. Water was collected from a nursery irrigation reservoir at a wholesale ornamental nursery located in eastern Virginia on 27 February, 6 April, and 7 June 2012 (Table 1, samples 1, 2, and 3, respectively). For each experiment, 10 liters of water were taken and filtered through membranes with pore sizes of 5.0 and $0.45 \mu \mathrm{m}$ to remove algae, zoosporic microorganisms and most bacteria in the water, eliminating their interference. Processed water was stored at $4^{\circ} \mathrm{C}$ and equilibrated to room temperature before $\mathrm{pH}$ measurement and use.

Compressed (50 psi) $\mathrm{CO}_{2}$ was bubbled through 2.5 liters of the filtered water in 3.8-liter plastic containers at a rate of 0.67 liter $\mathrm{min}^{-1}$ for $8 \mathrm{~min}$. This resulted in a $\mathrm{CO}_{2}$ concentration of approximately 4,000 ppm; this estimate was based on the $\mathrm{CO}_{2}$ mass flow rate with Boyle's law at $25^{\circ} \mathrm{C}$ and 1 atmosphere of pressure. The bubbled water was then immediately diluted with nonbubbled control water to obtain $\mathrm{CO}_{2}$ concentrations of 2,000, 1,000, 500, 250, 125,63 , and $0 \mathrm{ppm}$. The dilutions were made three independent times for each experiment, and $100 \mathrm{ml}$ of each dilution concentration was placed in 167-ml tissue culture containers (Greiner Bio) and used immediately. Duplicates were prepared for $\mathrm{pH}$ measurements with a UB10 pH/MV Meter (Denver Instrument) to estimate dissolved $\mathrm{CO}_{2}$ levels. $\mathrm{CO}_{2}$ injection reduced the $\mathrm{pH}$ of all three irrigation water samples. The $\mathrm{pH}$ of all samples injected with $\mathrm{CO}_{2}$ at 4,000 ppm and their dilutions are listed in Table 1. The dissolved $\mathrm{CO}_{2}$ levels were estimated with the aquarium $\mathrm{CO}_{2}$ calculator $\mathrm{CO}_{2}$ $=3 \times \mathrm{KH} \times 10^{(7-\mathrm{pH})}$ (http://www.fishfriend.com/aquarium_co2_ calculator.html). $\mathrm{KH}$ refers to carbonate hardness. It is measured in degrees and converted from $\mathrm{CaCO}_{3} \mathrm{ppm}\left(1^{\circ} \mathrm{KH}\right.$ is equal to $\mathrm{CaCO}_{3}$ at $17.9 \mathrm{ppm})$. Because $\mathrm{CaCO}_{3}$ in the irrigation water reservoir was $63 \mathrm{ppm}, \mathrm{KH}$ of the water samples was $3.5^{\circ}$. The injected $\mathrm{CO}_{2}$ levels were much higher than those estimated (Table 1) and many of the levels were outside the measurement range of water $\mathrm{CO}_{2}$ sensors currently on the market. As such, injected $\mathrm{CO}_{2}$ levels instead of dissolved $\mathrm{CO}_{2}$ levels were used throughout in this study.

Phytophthora spp. and zoospore suspension preparation. Isolates of $P$. megasperma (42D2), P. nicotianae (45H1), P. pini (previously $P$. citricola; $43 \mathrm{H} 1$ ), and $P$. tropicalis (7G9) from irrigation water as well as an annual vinca isolate of $P$. nicotianae (3A12) from Virginia were used in this study. Zoospore production followed the method described previously (18). Briefly, agar plugs of 
1-week-old cultures were grown in $10 \%$ clarified V8 juice broth at room temperature for 7 days for $P$. nicotianae and $P$. tropicalis and 3 days for $P$. megasperma and $P$. pini. After the media were decanted, the cultures were rinsed with sterile distilled water (SDW), drained, and exposed to light for 24 to $48 \mathrm{~h}$ for $P$. nicotianae and $P$. tropicalis and $8 \mathrm{~h}$ for $P$. megasperma. The rinsed $P$. pini culture was flooded with SDW and incubated under light for $8 \mathrm{~h}$ to facilitate sporangium production. After the light exposure, plates were refilled with chilled, sterile soil water extract. Zoospores were harvested by passing suspensions through a layer of sterile Miracloth (Calbiochem). Zoospores were then counted with a hemocytometer after $30 \mathrm{~min}$ for $P$. nicotianae and $P$. tropicalis and after overnight incubation under light for $P$. megasperma and $P$. pini. Suspensions at greater than $10^{4}$ zoospores $\mathrm{ml}^{-1}$ were used as stocks for working suspension preparation.

Agar plate assay for zoospore survival. A volume of stock zoospore suspension was added to the $\mathrm{CO}_{2}$ water series in individ- ual tissue culture containers to obtain a final zoospore concentration at 50 to 100 zoospores $\mathrm{ml}^{-1}$. Three $1-\mathrm{ml}$ samples were withdrawn from each container after $2 \mathrm{~h}$ of exposure and spread onto selective V8 agar medium plates (6). Emerging colonies were counted after a 2- to 3-day incubation at room temperature (22 to $25^{\circ} \mathrm{C}$ ). Each treatment included three replicate containers and the experiment was repeated twice with different water samples. The average number of colonies in control plates was used as the denominator to calculate relative survival rate of zoospores for each treatment.

Infection assay. Annual vinca (Catharanthus roseus 'Little Bright Eye') was seeded and grown on a mist bench for 5 weeks. Four seedlings were transplanted into pine bark in $15-\mathrm{cm}$ pots and grown for 8 to 10 weeks in the greenhouse before use. Zoospores of $P$. nicotianae (isolate $3 \mathrm{~A} 12$ ) were exposed to $\mathrm{CO}_{2}$ in the irrigation water sample from 7 June at designated concentrations for 30 min and $2 \mathrm{~h}$ before applying to the foliage. Zoospore concentra-

Table 1. Injected carbon dioxide $\left(\mathrm{CO}_{2}\right)$ concentrations and estimated dissolved $\mathrm{CO}_{2}$ levels in irrigation water samples ${ }^{\mathrm{a}}$

\begin{tabular}{|c|c|c|c|c|c|c|}
\hline \multirow[b]{2}{*}{$\mathrm{CO}_{2}(\mathrm{ppm})^{\mathrm{b}}$} & \multicolumn{2}{|c|}{ Water sample 1} & \multicolumn{2}{|c|}{ Water sample 2} & \multicolumn{2}{|c|}{ Water sample 3} \\
\hline & pH & $\mathrm{D}-\mathrm{CO}_{2}$ & pH & $\mathrm{D}-\mathrm{CO}_{2}$ & pH & D-COO \\
\hline 0 & 7.8 & 2 & 9.0 & 0 & 9.1 & 0 \\
\hline 63 & 7.6 & 3 & 7.8 & 2 & 7.5 & 3 \\
\hline 125 & 7.3 & 5 & 7.3 & 5 & 7.0 & 11 \\
\hline 250 & 6.7 & 21 & 6.9 & 13 & 6.6 & 26 \\
\hline 500 & 6.3 & 53 & 6.4 & 42 & 6.2 & 46 \\
\hline 1,000 & 6.0 & 105 & 6.0 & 105 & 5.9 & 132 \\
\hline 2,000 & 5.7 & 210 & 5.7 & 210 & 5.6 & 264 \\
\hline 4,000 & 5.2 & 663 & 5.3 & 526 & 5.1 & 834 \\
\hline
\end{tabular}

a Dissolved $\mathrm{CO}_{2}\left(\mathrm{D}-\mathrm{CO}_{2}\right)$ estimated based on measured $\mathrm{pH}$ and carbonate hardness of $3.5^{\circ}$.

${ }^{\mathrm{b}}$ Injected $\mathrm{CO}_{2}$ concentration; 2.5-liter irrigation water samples were bubbled with compressed $\mathrm{CO}_{2}$ at 0.67 liter min ${ }^{-1}$ for 8 min which resulted in $\mathrm{CO}_{2}$ at $4,000 \mathrm{ppm}$. The lower $\mathrm{CO}_{2}$ concentrations were established through dilutions.

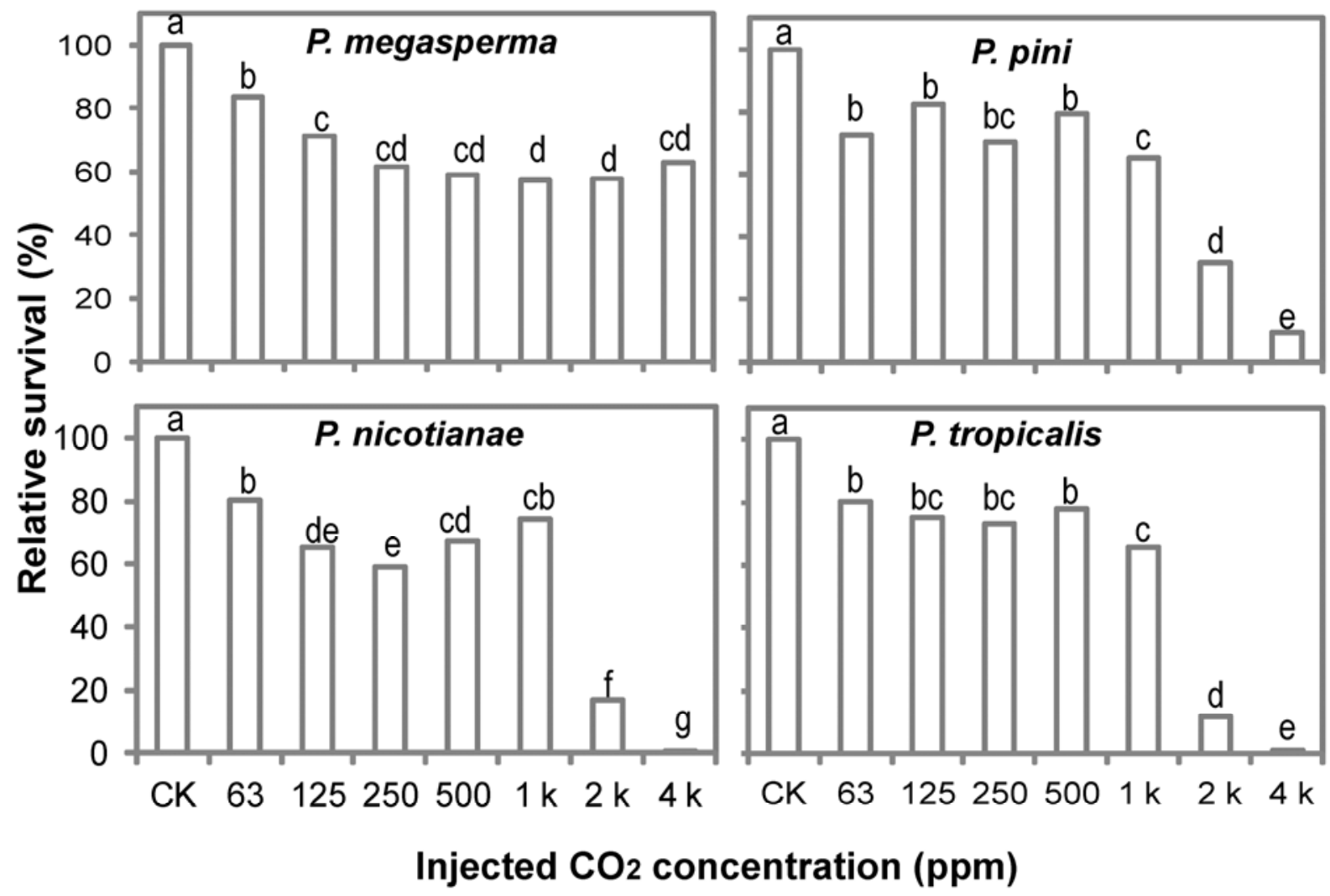

Fig. 1. Effect of injected carbon dioxide $\left(\mathrm{CO}_{2}\right)(0$ to $4,000 \mathrm{ppm})$ on zoospore survival of Phytophthora spp. in irrigation water samples. Untreated (CK) and treated water at indicated concentration levels in containers was infested with zoospores and incubated for $2 \mathrm{~h}$; then, 1 ml of the suspension was plated onto PARP medium. Emerged colonies in each plate were converted into relative survival (\%) by dividing by the average number of colonies in control plates. Letters on the top of columns indicate significance levels among $\mathrm{CO}_{2}$ treatments at $\alpha=0.05$ by least significant difference test. 
tions used were 1,000 and 5,000 zoospores $\mathrm{ml}^{-1}$, and an average of $7 \mathrm{ml}$ was sprayed onto plants in each container. To determine whether $\mathrm{CO}_{2}$ may cause phytotoxicity on plants, a treatment without zoospores was also included. Each treatment contained three replicate pots, and experiments were performed on 1 and 6 June 2012, respectively. Disease development was monitored and the number of total shoots and diseased shoots were recorded after symptoms fully developed ( 3 to 5 days post inoculation).

Data analysis. Data from repeated experiments were first analyzed for homogeneity, then pooled for further analysis of variance among treatments. Means were separated based on the least significant difference at $\alpha=0.05$ (SAS Institute, Inc.). The standard deviations among the experiments were calculated using Microsoft Excel.

\section{Results}

Effect of injected $\mathrm{CO}_{2}$ on zoospore survival in irrigation water. Irrigation water with and without injected $\mathrm{CO}_{2}$ from 63 to 4,000 ppm received zoospores of four Phytophthora spp., and the effect of $\mathrm{CO}_{2}$ concentrations on zoospore survival was examined. In general, as $\mathrm{CO}_{2}$ levels in irrigation water increased, zoospore survival decreased. Significant reduction of survival rates was ob-

Table 2. Significance levels of factors affecting annual vinca (Catharanthus roseus 'Little Bright Eye') disease incidence when inoculated with Phytophthora nicotianae zoospores sprayed onto foliage

\begin{tabular}{lrrr}
\hline Source & \multicolumn{1}{c}{ Mean } & \multicolumn{1}{c}{$\mathbf{F}$} & \multicolumn{1}{c}{$\boldsymbol{P}$} \\
\hline Experiment $^{\mathrm{a}}$ & 28.37 & 0.12 & 0.7343 \\
${\text { Exposure time }(\mathrm{T})^{\mathrm{b}}}^{\mathrm{b}}$ & $1,362.19$ & 5.56 & 0.0200 \\
$\mathrm{CO}_{2}$ concentration $(\mathrm{C}) \mathrm{c}^{\mathrm{c}}$ & $13,934.73$ & 56.86 & $<0.0001$ \\
${\mathrm{Zoospore} \mathrm{density}(\mathrm{Z})^{\mathrm{d}}}_{\mathrm{T} \times \mathrm{C}}$ & $14,425.18$ & 58.86 & $<0.0001$ \\
$\mathrm{~T} \times \mathrm{Z}$ & 428.41 & 1.75 & 0.1439 \\
$\mathrm{C} \times \mathrm{Z}$ & 829.12 & 3.38 & 0.0684 \\
$\mathrm{~T} \times \mathrm{C} \times \mathrm{Z}$ & 897.39 & 3.66 & 0.0075 \\
\hline
\end{tabular}

a Two experiments with irrigation water sample from June 2012.

${ }^{\mathrm{b}}$ Two exposures times at $30 \mathrm{~min}$ and $2 \mathrm{~h}$.

${ }^{\mathrm{c}}$ Five carbon dioxide $\left(\mathrm{CO}_{2}\right)$ concentrations, including control and injected $\mathrm{CO}_{2}$ at 250, 1,000, 2,000 and 4,000 ppm.

${ }^{\mathrm{d}}$ Two inoculum densities at 1,000 and 5,000 zoospores $\mathrm{ml}^{-1}$. served at as low as $63 \mathrm{ppm}(P<0.0001$; Fig. 1$)$. The reduction was much greater when injected $\mathrm{CO}_{2}$ concentrations were $2,000 \mathrm{ppm}$ or higher. Differences among species response to the treatments were detected, especially when $\mathrm{CO}_{2}$ concentrations were low (Fig. 1). $P$. megasperma was the most tolerant of $\mathrm{CO}_{2}$. The difference in zoospore survival between 250 and 4,000 ppm was not significant $(P=$ $0.9926)$. In contrast, $P$. nicotianae, $P$. pini, and $P$. tropicalis were much less tolerant and most zoospores did not survive at high concentrations of $\mathrm{CO}_{2}$. For $P$. pini, only 30 and $10 \%$ of the population survived at 2,000 and 4,000 ppm, respectively. P. nicotianae and $P$. tropicalis had similar responses but there was less than $20 \%$ population survival at $2,000 \mathrm{ppm}$ and almost no survival at 4,000 ppm. At $\mathrm{CO}_{2}$ concentrations of $1,000 \mathrm{ppm}$ and below, all three species survived well although there were some differences among $\mathrm{CO}_{2}$ concentrations $(P<0.0001)$.

Effect of injected $\mathrm{CO}_{2}$ in irrigation water on infectivity of zoospores. To determine whether $\mathrm{CO}_{2}$-treated water affects the ability of $P$. nicotianae (vinca isolate $3 \mathrm{~A} 12$ ) zoospores to infect plants, infested irrigation water with and without injected $\mathrm{CO}_{2}$ at 250, 1,000, 2,000 and 4,000 ppm for $30 \mathrm{~min}$ and $2 \mathrm{~h}$ was sprayed on annual vinca plants, and disease incidence was then recorded. Similar results were observed in two independent experiments and there was no difference between trials $(P=0.7343)$. There were significant differences among $\mathrm{CO}_{2}$ treatments between exposure times and inoculum concentrations as well as interactions among the three factors (Table 2). The treated water with $\mathrm{CO}_{2}$ concentrations of 2,000 and 4,000 ppm resulted in the most significant reduction of disease incidence (Fig. 2). Regardless of the length of exposure time, injected $\mathrm{CO}_{2}$ at $1,000 \mathrm{ppm}$ effectively lowered disease incidence at low density of inocula. However, longer exposure time $(2 \mathrm{~h})$ facilitated reduction of disease incidence resulted from the inoculum concentration at $1,000 \mathrm{ml}^{-1}$ when $\mathrm{CO}_{2}$ was at 250 ppm (Fig. 2). No damage was observed on plants sprayed with $\mathrm{CO}_{2}$-injected water even at $4,000 \mathrm{ppm}$, the highest concentration tested, indicating that $\mathrm{CO}_{2}$-injected water was not phytotoxic.

\section{Discussion}

This study advances previous work on the efficacy of pressurized $\mathrm{CO}_{2}(1,2)$ on controlling Phytophthora spp. and demonstrates that $\mathrm{CO}_{2}$ at a low pressure can be used to treat Phytophthora spp.-

\section{$\square C K \square 250 \square 1000$ 图2000 숭 4000 ppm}

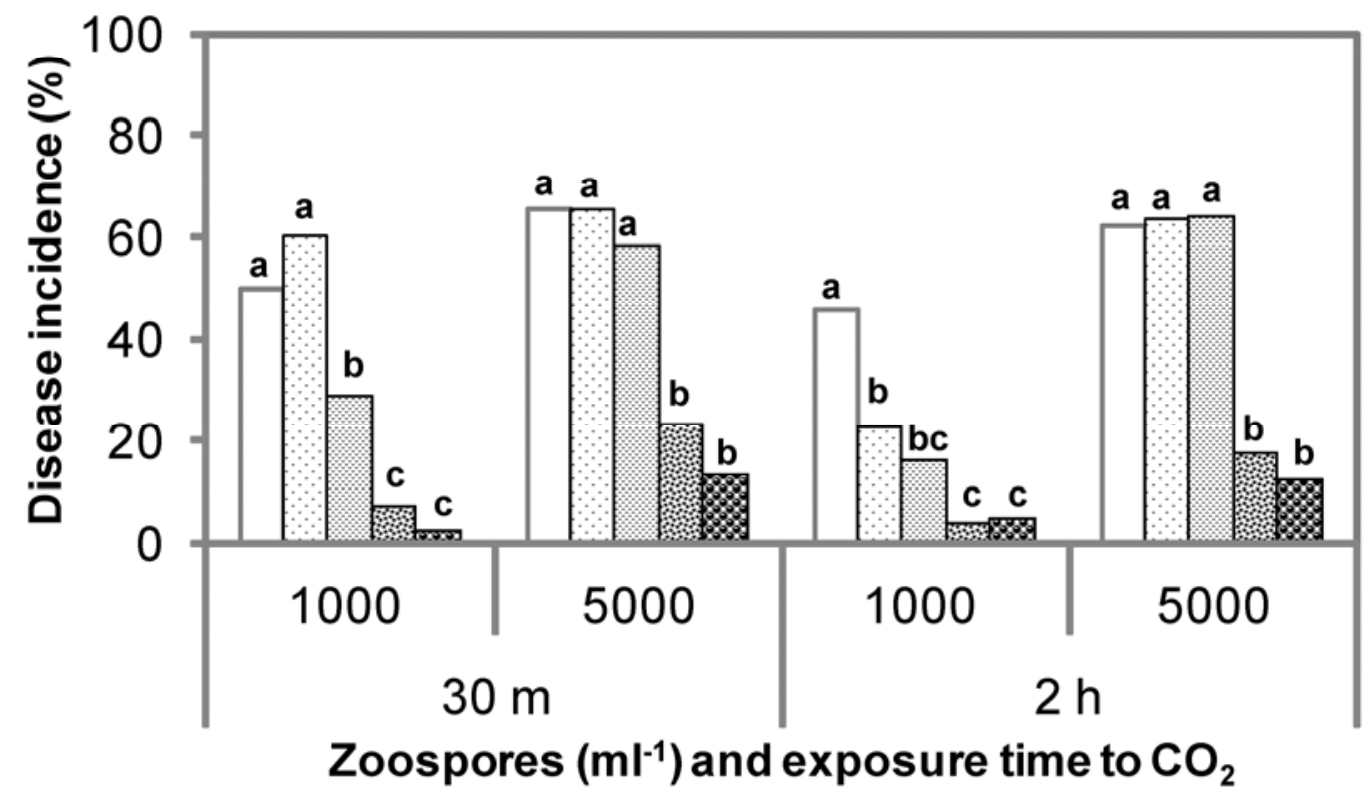

Fig. 2. Effect of injected carbon dioxide $\left(\mathrm{CO}_{2}\right)(0$ to $4,000 \mathrm{ppm})$ in irrigation water on disease incidence of annual vinca (Catharanthus roseus 'Little Bright Eye') by Phytophthora nicotianae zoospores. Untreated (CK) and treated water at indicated concentration levels was infested with zoospores at inoculum densities of 1,000 and 5,000 $\mathrm{ml}^{-1}$ for $30 \mathrm{~min}$ or $2 \mathrm{~h}$ and $7 \mathrm{ml}$ was sprayed onto the foliage. Disease incidence is indicated with percentage of diseased shoots assessed 3 days post inoculation. Columns topped with the same letter are not significantly different according to the least significant difference test $(\alpha=0.05)$. 
infested irrigation water, with the effectiveness dependent on the concentration, treatment time, pathogen species, and inoculum density. Injected $\mathrm{CO}_{2}$ at 2,000 ppm or higher for $2 \mathrm{~h}$ was effective for treating irrigation water with a zoospore density of $P$. nicotianae, $P$. pini, and $P$. tropicalis as high as 5,000 zoospores $\mathrm{ml}^{-1}$. Such a concentration was not effective for $P$. megasperma. Note that $P$. megasperma also tolerated a wide range of $\mathrm{pH}$ (18). The injection of $\mathrm{CO}_{2}$ into water could be used to reduce viable inocula and protect plants from disease outbreaks in the field. Further, it may be possible to inject lower concentrations of $\mathrm{CO}_{2}$ continuously into water in order to manage Phytophthora populations in irrigation systems where the pathogen is chronically present at low levels $(9,16)$. Although injected $\mathrm{CO}_{2}$ at 4,000 ppm can kill most zoospores within a few minutes (data not shown), levels of $\mathrm{CO}_{2}$ as low as $250 \mathrm{ppm}$ can reduce disease incidence. Such treatment in the present experiments resulted in a lowered inoculum level by $50 \%$ in $2 \mathrm{~h}$. To effectively use $\mathrm{CO}_{2}$ for waterborne Phytophthora spp. management, it is important to understand the differences in $\mathrm{CO}_{2}$ tolerance among species present in the system.

Although the efficacy of injected $\mathrm{CO}_{2}$ on zoosporic pathogen survival and plant infection is evident, the practicality of using $\mathrm{CO}_{2}$ for water treatment must be assessed in terms of cost. One pound of compressed $\mathrm{CO}_{2}$ can treat 227 liters (60 gallons) of water to obtain $\mathrm{CO}_{2}$ at 2,000 ppm for effective decontamination of severely infested water $\left(5,000\right.$ zoospores $\left.\mathrm{ml}^{-1}\right)$. The cost is $\$ 8.3$ per 3,785 liters (1,000 gallons) of water or $\$ 2.2$ per 1,000 liters, given that compressed $\mathrm{CO}_{2}$ is $\$ 0.5$ per pound. Concentrations of $P$. nicotianae and other Phytophthora spp. are normally low (33 to $570 \mathrm{CFU} / \mathrm{liter}$ in the case of $P$. nicotianae; 12,16); thus, injected $\mathrm{CO}_{2}$ concentration for regular water treatment could be as low as $250 \mathrm{ppm}$, consequently reducing the cost to $\$ 0.26$ per 1,000 liters ( $\$ 1$ per 1,000 gallons) of water. This cost is greater than chlorine gas at the effective concentration of $2 \mathrm{ppm}(0.025$ per 1,000 gallons or $\$ 6.6$ per million liters; 13). However, the hazards inherent in chlorine gas handling, the cost of training workers to handle chlorine safely, the cost of the equipment needed, and its low effectiveness at high $\mathrm{pH}$ must be considered. Operation with compressed $\mathrm{CO}_{2}$ does not require extensive training. A compressed $\mathrm{CO}_{2}$ leak is not hazardous unless it occurs in an enclosed space. Also, $\mathrm{CO}_{2}$ has other advantages over chlorine gas. For example, it reduces the $\mathrm{pH}$ of water with minimal impact on its effectiveness. $\mathrm{CO}_{2}$ treatment could be used in combination with chlorine gas, reducing the water $\mathrm{pH}$ to levels optimal for chlorination.

\section{Acknowledgments}

This study was supported, in part, by the Virginia Nurserymen's Horticulture Research Foundation and by the United States Department of Agriculture National Institute of Food and Agriculture Specialty Crop Research Initiative (agreement number 2010-51181-21140). I thank P. Richardson, J. Zhang, M. Pistininzi, C. Hong, and G. Moorman for taking water samples, assistance in this study, or comments and suggestions on this manuscript.

\section{Literature Cited}

1. Ahonsi, M. O., Banko, T. J., Doane, S. R., Demuren, A. O., Copes, W. E., and Hong, C. X. 2010. Effects of hydrostatic pressure, agitation and $\mathrm{CO}_{2}$ stress on Phytophthora nicotianae zoospore survival. Pest Manage. Sci. 66:696-704.

2. Banko, T. J., Richardson, P. A., and Hong, C. X. 2006. Effects of zoospore concentration and application pressure on foliage blight of Catharanthus roseus caused by Phytophthora nicotianae. Plant Dis. 90:297-301.

3. Chastagner, G., Oak, S., Omdal, D., Ramsey-Kroll, A., Coats, K., Valachovic, Y., Lee, C., Hwang, J., Jeffers, S., and Elliott, M. 2009. Spread of $P$. ramorum from nurseries into waterways-implications for pathogen establishment in new areas. Gen. Tech. Rep. PSW-GTR 229:22-26.

4. Cheftel, J. C. 1995. Review: high-pressure, microbial inactivation and food preservation. Food Sci. Technol. Int. 1:75-90.

5. Cheng, X. H., Imai, T., Teeka, J., Yamaguchi, J., Hirose, M., Higuchi, T., and Sekine, M. 2011. Inactivation of Escherichia coli and bacteriophage T4 by high levels of dissolved $\mathrm{CO}_{2}$. Appl. Microbiol. Biotechnol. 90:14931500 .

6. Ferguson, A. J., and Jeffers, S. N. 1999. Detecting multiple species of Phytophthora in container mixes from ornamental crop nurseries. Plant Dis. 83:1129-1136.

7. Ferrentino, G., and Spilimbergo, S. 2011. High pressure carbon dioxide pasteurization of solid foods: current knowledge and future outlooks. Trends Food Sci. Technol. 22:427-441.

8. Garcia-Gonzalez, L., Geeraerd, A. H., Spilimbergo, S., Elst, K., Van Ginneken, L., Debevere, J., Van Impe, J. F., and Devlieghere, F. 2007. High pressure carbon dioxide inactivation of microorganisms in foods: the past, the present and the future. Int. J. Food Microbiol. 117:1-28.

9. Ghimire, S. R., Richardson, P. A., Moorman, G. W., Lea-Cox, J. D., Ross, D. S., and Hong, C. X. 2009. An in-situ baiting bioassay for detecting Phytophthora species in irrigation runoff containment basins. Plant Pathol. 58:577-583.

10. Hong, C. X., Lea-Cox, J. D., Ross, D. S., Moorman, G. W., Richardson, P. A., Ghimire, S. R., and Kong, P. 2009. Containment basin water quality fluctuation and implications for crop health management. Irrig. Sci. 29:485496.

11. Hong, C. X., and Moorman, G. W. 2005. Plant pathogens in irrigation water: challenges and opportunities. Crit. Rev. Plant Sci. 24:189-208.

12. Hong, C. X., Richardson, P. A., and Kong, P. 2002. Comparison of membrane filters as a tool for isolating pythiaceous species from irrigation water. Phytopathology 92:610-616.

13. Hong, C. X., Richardson, P. A., Kong, P., and Bush, E. A. 2003. Efficacy of chlorine on multiple species of Phytophthora in recycled nursery irrigation water. Plant Dis. 87:1183-1189.

14. Hrudey, S. E. 2009. Chlorination disinfection by-products, public health risk tradeoffs and me. Water Res. 43:2057-2092.

15. Kobayashi, F., Ikeura, H., Odake, S., Tanimoto, S., and Hayata, Y. 2012 Inactivation of Lactobacillus fructivorans suspended in various buffer solutions by low-pressure $\mathrm{CO}_{2}$ microbubbles. Lwt-Food Sci. Technol. 48:330333.

16. Kong, P., Hong, C. X., Jeffers, S. N., and Richardson, P. A. 2003. A speciesspecific polymerase chain reaction assay for rapid detection of Phytophthora nicotianae in irrigation water. Phytopathology 93:822-831.

17. Kong, P., Moorman, G. W., Lea-Cox, J. D., and Hong, C. X. 2012. Survival of Phytophthora alni, P. kernoviae and P. ramorum in a simulated aquatic environment at different levels of pH. FEMS Microbiol. Lett. 332:54-60

18. Kong, P., Moorman, G. W., Lea-Cox, J. D., Ross, D. S., Richardson, P. A., and Hong, C. X. 2009. Zoosporic tolerance to $\mathrm{pH}$ stress and its implications for Phytophthora species in aquatic ecosystems. Appl. Environ. Microbiol. 75:4307-4314.

19. Li, H., Deng, L., Chen, Y., and Liao, X. J. 2012. Inactivation, morphology, interior structure and enzymatic activity of high pressure $\mathrm{CO}_{2}$-treated Saccharomyces cerevisiae. Innovative Food Sci. Emerg. Technol. 14:99-106.

20. Mushtaq, M., Banks, C. J., and Heaven, S. 2012. Effectiveness of pressurised carbon dioxide for inactivation of Escherichia coli isolated from sewage sludge. Water Sci. Technol. 65:1759-1764.

21. Rajagopal, M., Werner, B. G., and Hotchkiss, J. H. 2005. Low pressure $\mathrm{CO}_{2}$ storage of raw milk: microbiological effects. J. Dairy Sci. 88:3130-3138.

22. Rossi-Fedele, G., Guastalli, A. R., Dogramaci, E. J., Steier, L., and De Figueiredo, J. A. P. 2011. Influence of $\mathrm{pH}$ changes on chlorine-containing endodontic irrigating solutions. Int. Endod. J. 44:792-799.

23. Segall, R. H. 1968. Fungicidal effectiveness of chlorine as influenced by concentration, temperature, $\mathrm{pH}$, and spore exposure time. Phytopathology 58:1412-1414.

24. Shimoda, M., Cocunubo-Castellanos, J., Kago, H., Miyake, M., Osajima, Y., and Hayakawa, I. 2001. The influence of dissolved $\mathrm{CO}_{2}$ concentration on the death kinetics of Saccharomyces cerevisiae. J. Appl. Microbiol 91:306-311.

25. Singh, P., Wani, A. A., Karim, A. A., and Langowski, H. C. 2012. The use of carbon dioxide in the processing and packaging of milk and dairy products: a review. Int. J. Dairy Technol. 65:161-177.

26. Tjosvold, S. A., Chambers, D. L., Koike, S. T., and Mori, S. R. 2008. Disease on nursery stock as affected by environmental factors and seasonal inoculum levels of Phytophthora ramorum in stream water used for irrigation. Plant Dis. 92:1566-1573.

27. Valley, G., and Rettger, L. F. 1927. The influence of carbon dioxide on bacteria. J. Bacteriol. 14:101-137. 